\title{
チャンバー内吸着-加熱脱着法による準揮発性有機化合物 (SVOCs) 放散量測定 一測定精度の検証と各種材料の測定一 \\ MEASUREMENT OF SVOCs EMITTED FROM VARIOUS KINDS OF INDOOR MATERIALS BY THERMAL DESORPTION TEST CHAMBER METHOD
}

\author{
勝又寛子*, 村上周三**, 加藤信介***, 星野邦広****, 安宅勇二***** \\ Hiroko KATSUMATA, Shuzo MURAKAMI, Shinsuke KATO, \\ Kunihiro HOSHINO and Yuji ATAKA
}

\begin{abstract}
This paper presents measurements of SVOCs (semi-volatile organic compounds) emitted from building materials, household electric appliances, and products in a room. Until now many reports have been published on the emission test chamber method for measuring VOCs (volatile organic compounds), whereas there are very few reports on the measurement of SVOCs In this paper, we apply the thermal desorption test chamber method that we developed to measurements of SVOCs. This method can measure correctly the emission rate of SVOCs emitted from materials under actual room air temperature conditions.
\end{abstract}

Keywords: SVOCs, Emission, Adsorption, Thermal desorption, Chamber, Room temperature 準揮発性有機化合物、放散、吸着、加熱脱着、チャンバー、室温

\section{1. はじめに}

近年、深刻な社会問題となったシックハウス問題では、ホルムア ルデヒド測定のための小形チャンバー法の JIS 化を始めとして、様々 な対応がなされている文1)。ところが、従来シックハウスの主な原因 物質とされてきたホルムアルデヒド等に十分配慮して作られた建物 でも、依然として居住者がシックハウスの症状を訴えるという事例 が多数報告されている。このような状況に対し、室内に存在する各 種材料から空気中に放散する恐れのある化学物質について、より詳 細な調査が求められている。

その中でも、建材・内装材・家具・家電製品等の様々な材料に可 塑㓮として含まれている準揮発性有機化合物(SVOCs: Semi-Volatile Organic Compounds:沸点 $240 \sim 400^{\circ} \mathrm{C}$ ) 注 1)の健康影響が悬念されている。 特に厚生労働省が室内濃度指針值を策定しているフタル酸ジ-n-ブチ ル(DBP: Di-n-butyl phthalate)やフタル酸ジ-2-エチルヘキシル(DEHP: Di2-ethylhexyl phthalate )などのフタル酸エステル類は、SVOCs の代表的 な物質であり、年間約 45 万 $\mathrm{t}$ 生産されている可塑阂のうち $80 \%$ を占 めている文2)。海外の研究では、子供の喘息やアレルギー症状と、家 庭のハウスダスト中に含まれる DEHP 濃度の間に相関性がみられる という報告もなされている文)。しかしながら、現在、材料から放散 する SVOCsに関する報告例は少なく文4 8)、特にこれらの物質を対象 に室温度条件下での放散量調查をする事が望まれている。

筆者らは室温度条件下での SVOCs の測定に適したチャンバー内 吸 着一加熱脱着法を開発し、様々な材料の測定を行い、報告している文 〜16)。SVOCs を測定するためには、極微量の分析を行わなければなら ないため、測定精度を確保する事が非常に難しい。そこで本報では、 加熱脱着用チャンバーによる測定の精度検証結果を報告する。測定
精度の検証は、標準物質による回収率測定実験、床材試験片を用い た測定の繰り返し再現性拄 2)調查をもとに行う。また、床材からの SVOCs 放散の特徵についても調查する。これらを踏まえ、測定法の 応用例として様々な材料の測定を行ったので、併せて報告する。実験 結果では、VOCs である Dodecane, Tridecane, 2-Ethyl 1-Hexanol (2E1H: DEHPの分解物質である)等についても参考物質として併記する。

\section{2. 材料測定の概要}

2.1 チャンバー内吸着-加熱脱着法(図 1、式 1 )

測定システムフローを図 1 に示す。SVOCs は、室温条件下ではチ ヤンバー壁面に吸着しやすい。チャンバー内 吸着 - 加熱脱着法は、 その吸着成分を考慮した放散量の測定法である。室温条件下で試験 片から放散されるガスを捕集後(見掛けの放散ガスの測定 ${ }^{\text {注 }}{ }^{3)}$ )、チャ ンバーから試験片を取り除いて高温加熱し、チャンバー内に吸着し

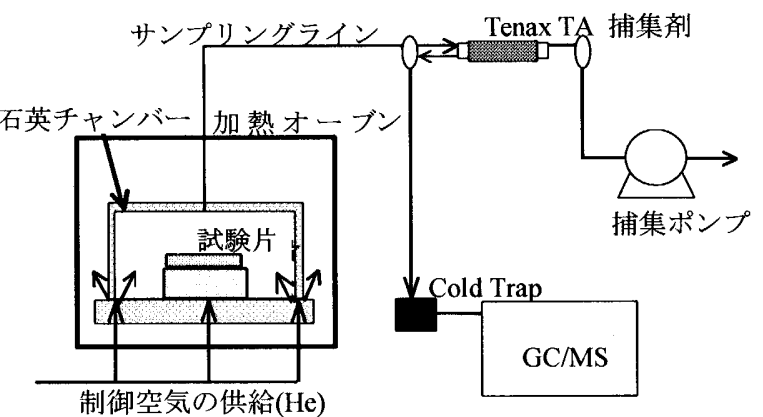

図 1 測定システムフロー 
ている SVOCs 成分を捕集し(チャンバー内 吸着成分の測定)、両者の 和により放散速度を評価する(式 1)。

\section{2 測定及び分析方法(図 2, 、表 1)}

測定フローを図 2、測定条件を表 1 に示す。加熱脱着装置として、 MSTD-258A(ジーエルサイエンス製)を用いた。捕集剤には Tenax $\mathrm{TA}$ を用い(脱着温度 $270^{\circ} \mathrm{C}$ )、ガスクロマトグラフ質量分析計 $(\mathrm{GC} /$ MS)により定性·定量分析を行う注 4)。サンプリングラインは、吸着を 防ぐために、石英コーティングされ、 $270^{\circ} \mathrm{C} て ゙$ 保温されている。ここ で、プレパージは、サンプリングライン等の残存物質や試験片設置 に伴い混入した污染物質を排気する事を目的として行う。

\section{3 チャンバーの概要(図 3)}

図 3 にチャンバーの構造を示す。チャンバーの材質は石英で、有 機化合物の吸着や分解が比較的起こりにくく不活性である。チャン バ一容積は $3.9 \times 10^{-4} \mathrm{~m}^{3}$ で、換気回数は 9.5 回 $/ \mathrm{h}$ 注 5$)$ とし、不活性ガス

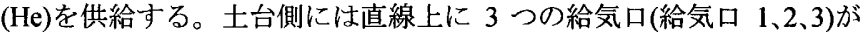
並び、上蓋中央に捕集口が配置してある。給気口 1.3 を含む土台表 面と上蓋の縁部分には僅かな隙間がある。この隙間部分からの外気 の流入を防ぐために、チャンバーの土台に円周上の溝を設け、この 部分に給気を行うことでチャンバー内部を正圧に保つ構造となって いる。

\section{3. 测定精度の検証}

\section{1 回収率測定 (図 4)}

材料から放散した SVOC がチャンバー壁面に吸着する事を想定し、 SVOC 標淮物質を用いて回収率を算出する。チャンバー内の各位置 に標準物質 $1 \mu$ 1(濃度:100ng/ $\mu$ 1)を添加し、加熱脱着して得られた捕 集量から各添加位置における回収率を算出している注 6)。加熱脱着は 表 1 の(2)吸着成分の測定と同条件で行う。

1）SVOCs 標淮物質の添加位置

チャンバー内部にガラス台 $(\phi 60 \mathrm{~mm} \times 30 \mathrm{~mm}(\mathrm{H}))$ を設置しており、 ガラス台上面を試験片の設置位置と想定している(図 4) 注7)。標準物質 の添加位置はチャンバー内に 4 ヶ所 (1)チャンバー天井面、(2)ガラス 台上面、(3)側壁面 $1\left(0^{\circ}\right.$ 地点 : 給気口 1 の真上のチャンバー壁面を基 準 $0^{\circ}$ 地点とする)、(4)側壁面 $2\left(90^{\circ}\right.$ 地点 : 基準地点から円周上に $90^{\circ}$ の 位置)設けている。

2）回収率に関する実験結果

DEHPについて、各添加位置における回収率の結果を図 4 に示す。 回収率は(1)天井面：98\%、(2)ガラス台上面：97\%、(3)側壁面 $1\left(0^{\circ}\right.$ 地 点) : $66 \%$ 、(4)側壁面 2 (90 地点) : $59 \%$ となった。回収率は、添加位 置によって異なり 59〜98\%となった。

\section{2 㦿材による精度検証 (図 5)}

試験片からの放散量測定に基づく精度検証を行う。試験片として 塩化ビニル製の床材を用いた。ロール状の床材中央から試験片を切 り出す。試験片のサイズは、放散面を $70 \mathrm{~mm} \times 70 \mathrm{~mm}$ とし、放散面以 外は、アルミはくでシール加工した。

1）養生条件

養生には、デシケータを用いた。容器側面の入り口から、清浄空 気注 ${ }^{8)}$ 給気、天井中央部から排気した。容器の密閉性を保ち、試験 片出し入れの時のみ開放した。試験片をシール加工後、デシケータ 内に設置し、養生開始(養生日数:0日)とした。

2）測定の繰り返し再現性 (試験片 $\mathbf{a}$ :図 5)

試試験片 1 枚をデシケータ内に設置し、盖生開始から 1 日後に取 り出し、5 回連続で測定した注9。

変動係数 (CV 值) は、DEHP の分解物質である 2E1H(2-Ethyl 1-

$$
\begin{aligned}
& \text { 放散速度 }\left[\mu \mathrm{g} /\left(m^{2} h\right)\right] \\
& =\frac{(\text { 見挂けの放散量 }[\mu \mathrm{g}]+\text { +チャンバー内吸着量 }[\mu \mathrm{g}])}{\text { 放散面積 }\left[m^{2}\right] \times \text { 放散時間 }[h] .}
\end{aligned}
$$

養生プレパージ (1)放散ガス測定 プレパージ (2)吸着成分の測定

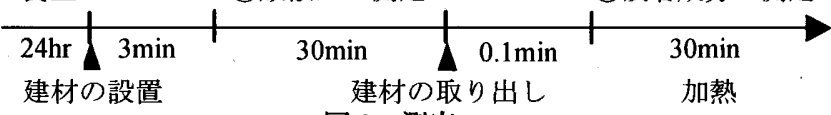

図 2 測定フロー

表 1 測定条件

\begin{tabular}{|c|c|c|}
\hline & (1)放散ガス測定 & (2)吸着成分の測定 \\
\hline オーブン温度 & $28^{\circ} \mathrm{C}$ & $\begin{array}{c}28^{\circ} \mathrm{C}-250^{\circ} \mathrm{C} \\
\left.\text { (Rate } 20^{\circ} \mathrm{C} / \mathrm{min}\right)\end{array}$ \\
\hline 捕集時間 & $30 \mathrm{~min}$ & $30 \mathrm{~min}$ \\
\hline プレパーシ時間 & $3.0 \mathrm{~min}$ & $0.1 \mathrm{~min}$ \\
\hline パージガス流量 & $100 \mathrm{ml} / \mathrm{min}$ (捕集流量 $50 \mathrm{ml} / \mathrm{min}$ ) \\
\hline
\end{tabular}

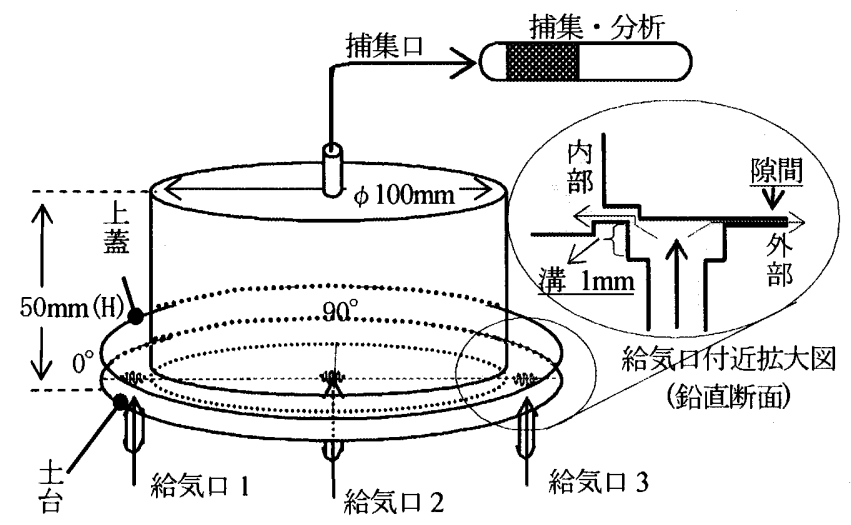

図 3 チャンバー概要

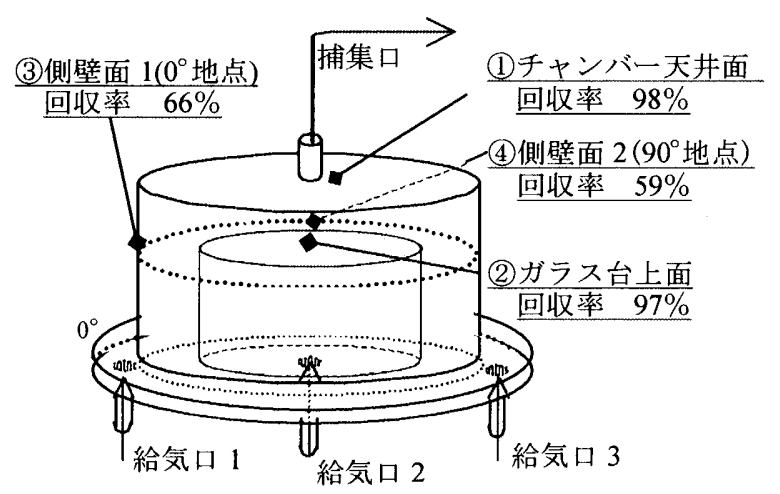

図 4 各添加位直における回收率

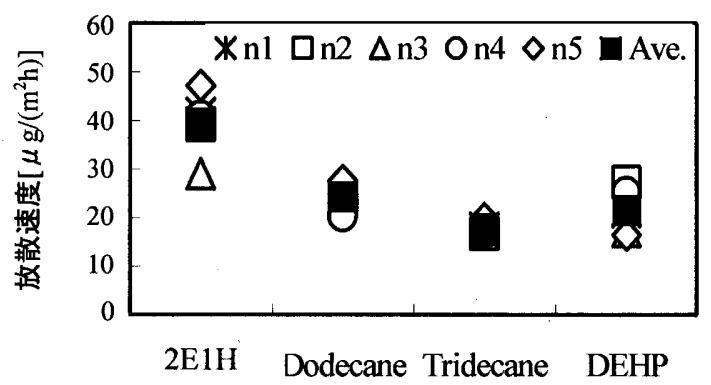

图 5 測定の繰り返し再現性(4物質)：試䀦片 a 
Hexanol):17\%、Dodecane:11\%、Tridecane:7\%、DEHP:22\%であった。 平均放散速度は、2E1H: $39 \mu \mathrm{g} /\left(\mathrm{m}^{2} \mathrm{~h}\right)$ 、Dodecane: $24 \mu \mathrm{g} /\left(\mathrm{m}^{2} \mathrm{~h}\right)$ 、 Tridecane: $18 \mu \mathrm{g} /\left(\mathrm{m}^{2} \mathrm{~h}\right) 、$ DEHP: $22 \mu \mathrm{g} /\left(\mathrm{m}^{2} \mathrm{~h}\right)$ であった。

\section{4. 床材からの SVOCs 放散特性}

\section{1 養生日数と放散量の関係(試験片 $\mathrm{b}$ :図 6,7)}

試験片 1 枚をデシケータ内に設置し、養生開始から 6 日後まで、1 日ごとに試験片を測定した(4 日目欠測)。図 6 にVOCs である Dodecane と Tridecane について、図 7 に SVOCs である DEHPについ て、養生日数と放散速度减衰の関係を示す。 3.2 で算出した変動係数 を用いて誤差範囲を示している。Dodecane、Tridecane は養生日数経 過と共に放散速度が減衰し、6 日目の測定值では、1 日目の 3 4 割 まで減少している。一方、DEHP は減衰傾向が見られなかった。5 回 の測定の平均放散速度は、 $22 \mu \mathrm{g} /\left(\mathrm{m}^{2} \mathrm{~h}\right)$ であった。

4.2 切り出し位膡と放散量の関係(試験片 $\mathrm{c} \sim \mathrm{h}$ : 図 8,9、表 2)

図 8 に示すように、試験片の一辺が製品の長手方向と平行になる ように試験片 6 枚(c h)を切り出す。その後デシケータ内に 6 枚を設 置し、養生開始から 1 日後、それぞれ測定した。図 9 に切り出し位 置と DEHP. の放散量の関係、表 2 に各物質の放散速度のばらつきを 変動係数で示す。放散量の多い 4 物質については、材料中央から切 り出した試験片 eからの放散が最大であった。

\section{5. チャンバーの性能と床材からの SVOCs 放散特性に関する考察} 5.1 チャンバー内吸着分の回収率

チャンバー天井面及びガラス台上面の回收率は、98\%、97\%と高 いことがわかる。しかしながら、側壁面に添加した場合は、回収率 が 66\%、59\%となった。回収率の低い原因として、以下に示す $3 つ$ の要因が挙げられる。(1)固体壁面(チャンバー内部表面とガラス台)へ 2 次吸着し、その後脱着されない事による低下。(2)チャンバーからの リーク(液滴を添加した直後、蓋をするまでに揮発し漏れる)による低 下。(3)チャンバーからのリーク(測定中空気流動により隙間から漏れ る)による低下。(2)については、プレパージ時間を 0.1 分と短く設定 しているため影響はないと考えている。また、(3)につては、側壁 面吸着分について漏れの可能性があると考えている。しかし、この 事による材料測定への影響については、今回の流量バランスでは、 材料測定位置であるガラス台上面から天井までの空間の流れは捕集 口に向かっている事を数值シミュレーションにより確認しており文 ${ }^{16)}$ 、 材料測定への影響はないと考えている。

\section{2 測定の繰り返し再現性}

同一の試験片を繰り返し測定する事で、本測定法の繰り返し再現 性を検証した。放散成分ごとの繰り返し再現性の比較では、VOCs 類 である Dodecane、Tridecane は CV 值が低く繰り返し再現性が高かっ た。DEHP とその分解物質である $2 \mathrm{E} 1 \mathrm{H}$ は、上述した VOCs 類と比較 して CV 值が $20 \%$ 程度と高い。

\section{3 養生日数と DEHP 放散量の関係}

図 6 に示す 5 回分の測定の変動係数を直接算出したところ、 $28 \%$ と なった。この変動は、装置に由来する系統誤差(3.2で算出した繰り返

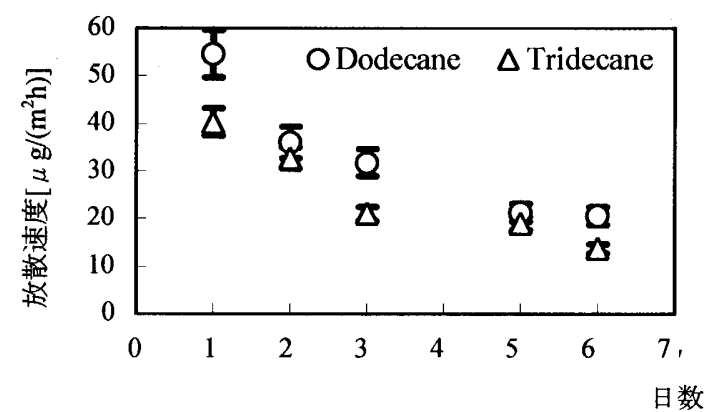

図 6 美生日数と放散量(VOCs): 試験片 b

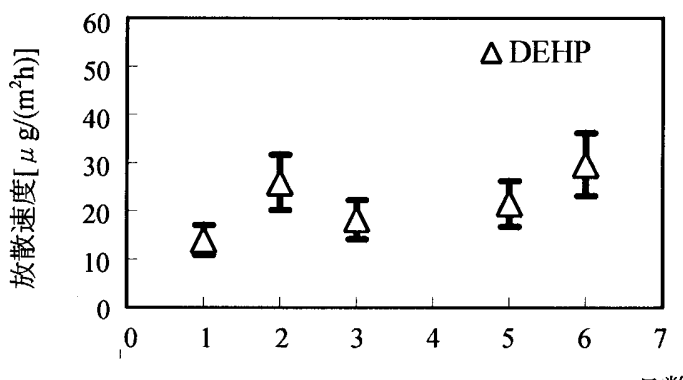

図 7 養生日数と放散量(SVOCs) : 試酸片 b

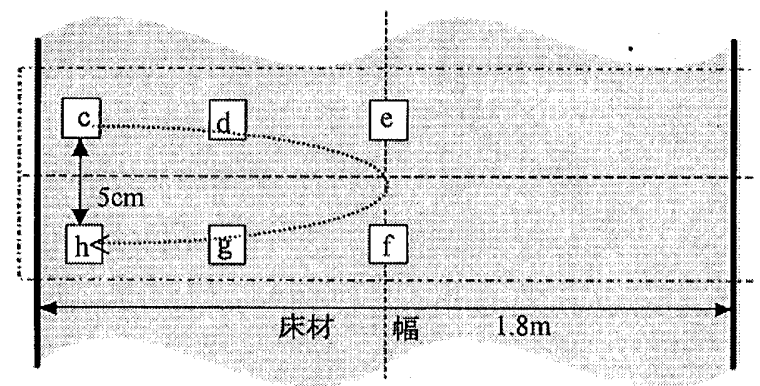

図 8 床材試験片の切り出し位置 : 試酫片 c-h

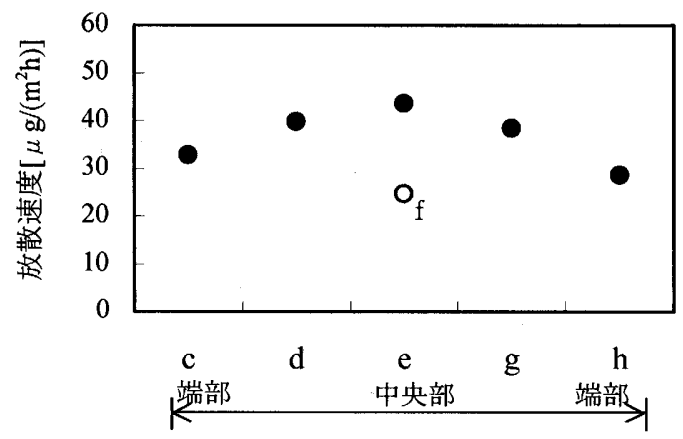

図 9 切り出し位置と放散量の関係 : 試験片 c-h

表 2 切り出し位膡と放散量のばらつき

\begin{tabular}{|c|c|c|c||c|}
\hline \multirow{2}{*}{} & \multicolumn{3}{|c||}{ 放散速度 $\left[\mu \mathrm{g} /\left(\mathrm{m}^{2} \mathrm{~h}\right)\right]$} & 変動 \\
\cline { 2 - 4 } & 平均值 & 最大値 & 最小値 & 係数 $[\%]$ \\
\hline $2 \mathrm{E} 1 \mathrm{H}$ & 69 & $104(\mathrm{e})$ & $49(\mathrm{~d})$ & \pm 32 \\
\hline Dodecane & 42 & $59(\mathrm{e})$ & $32(\mathrm{~d})$ & \pm 27 \\
\hline Tridecane & 45 & $60(\mathrm{e})$ & $31(\mathrm{f})$ & \pm 22 \\
\hline DEHP & 35 & $44(\mathrm{e})$ & $25(\mathrm{f})$ & \pm 21 \\
\hline
\end{tabular}


し誤差を含む)と放散現象の日変化により構成されるが、繰り返し誤 差 $22 \%$ に因るところが大きいと考えられる。繰り返し誤差の影響を 考虑すれば、6 日間の測定中 DEHP の放散速度は $22 \mu \mathrm{g} /\left(\mathrm{m}^{2} \mathrm{~h}\right)$ でほぼ 平衡状態であったと考えられる。

\section{4 切り出し位置と放散量の関係}

図 9 に示すように、DEHP の放散量は、材料中央から切り出した 試験片が最も高く、端部に行くに従い放散量が減少している。f に関 しては、材料端部からの距離が同じグループである c-h、d-g の放散 速度は、それぞれほぼ一致していることから、測定ミスであると考 えられる。この結果 4 物質で比較すると、切り出し位置の違いによ る放散のばらつきは、DEHPが CV 値 21\%で最も小さかった。また、 6 枚の試験片の平均放散速度が $35 \mu \mathrm{g} /\left(\mathrm{m}^{2} \mathrm{~h}\right)$ であり、上述した $3.2 、 4.1$ における平均放散速度 $22 \mu \mathrm{g} /\left(\mathrm{m}^{2} \mathrm{~h}\right)$ より高くなった原因として、養生 時に 1 つのデシケータに 6 枚の試験片を入れた事などが考えられる。

\section{6. 材料の測定}

\section{1 測定対象サンプル}

材料の測定は、9 製品、11 部位を対象とした。放散量測定を行っ た試験片を表 3 に示寸。これらは可塑剤や難燃剂等を含む可能性が ある建材や製品である。各試験片のサイズは、放散面を $70 \mathrm{~mm} \times$ 70mm とし、放散面以外は、アルミはくでシール加工した。

\section{2 測定温度条件}

試験片 $\mathrm{A}) \sim \mathrm{E})$ の雲囲気設定温度は $28^{\circ} \mathrm{C} 、 40^{\circ} \mathrm{C}$ の 2 ケースとした。 $28^{\circ} \mathrm{C}$ は室温条件下、 $40^{\circ} \mathrm{C}$ は、日当たりの良い場所で表面温度が上梨 することを想定した。F)ソファーカバーは、 $28^{\circ} \mathrm{C}$ の測定のみを行う。 G)ノートパソコンは、使用で温度が上梨することを想定し、 $40^{\circ} \mathrm{C} の$ 測定のみ行う。

\section{3 测定結果}

試験片 A) ～E)の測定結果を表 4 に、F)の測定結果を表 5 に、G)の測 定結果を表 6 に示す。

\section{A) 防ダ二加工した断熱材 (表 4:28 ${ }^{\circ} \mathrm{C}, 40^{\circ} \mathrm{C}$ )}

見措けの放散ガスの測定(雾囲気温度 $28^{\circ} \mathrm{C} 、 40^{\circ} \mathrm{C}$ )では、SVOCs は 検出されず、試験片から放散した SVOCs はチャンバー内吸着すると 考えられる。試験片を除いてチャンバーを高温加熱し $\left(28^{\circ} \mathrm{C} 、 40^{\circ} \mathrm{C} \rightarrow\right.$ $250^{\circ} \mathrm{C}$ )、チャンバー内吸着成分の測定を行った所、Diphenyl Sulfone やフタル酸エステル類である DEHP 等が検出された。Diphenyl Sulfone は、断熱材の発泡剂として用いられている可能性がある文 ${ }^{17) 。 ~}$ VOCs としては、Dodecane 等の脂肪族炭化水素が多く放散された。 脂肪族炭化水素はあらゆる溶剤に用いられる。これらは官能基を含 まず、生態への影響は比較的少ないとされている文18)。また DEHP の加水分解物質である $2 \mathrm{E} 1 \mathrm{H}$ が検出された。

B) 床材(表 $4: 28^{\circ} \mathrm{C}, 40^{\circ} \mathrm{C}$ 、図 $10: 28^{\circ} \mathrm{CTIC}$ 応答)

見掛けの放散ガスの測定で SVOCs として BHT(Butylated hydroxytoluene) が検出された。BHT は化学合成品や、プラスチック、 ヨ゙ム老化防止剤、酸化防止剤として利用されている文 ${ }^{18)}$ 。チャンバ 一内吸着成分の測定で DEHP が主に検出された。 $40^{\circ} \mathrm{C}$ の条件下の放 散速度は、 $28^{\circ} \mathrm{C}$ 条件下の 2〜5 倍であった。VOCs としては Phenol、 2E1Hが検出された

C) 壁紙(塩化ビニル系) (表 $4: 28^{\circ} \mathrm{C}, 40^{\circ} \mathrm{C}$ )

SVOCs は、チャンバー内吸着成分の測定においても検出されなか った。VOCs としては、見掛けの放散ガスの測定で Phenol、2E1H 等 が検出された。 $40^{\circ} \mathrm{C}$ 放散速度は、 $28^{\circ} \mathrm{C}$ 条件下の約 4 倍であった。
表 3 試阿片の種類

\begin{tabular}{|c|c|c|}
\hline 記号 & 種類 & $\begin{array}{l}\text { 厚さ } \\
(\mathrm{mm})\end{array}$ \\
\hline A) & 防ダ二加工した断熱材 (ホームセンターで購入) & 8.30 \\
\hline B) & 床材 (塩化ビニル系) & 1.90 \\
\hline C) & 壁紙 (塩化ビニル系) & 0.60 \\
\hline D) & カーペット (ホームセンターで購入) & 3.95 \\
\hline E) & 防炎カーテン (1 年前に購入) & 0.65 \\
\hline F) & $\begin{array}{l}\text { ソファーレザーカバー(ホームセンターで購入) } \\
\text { (1)A 社製、(2)B 社製、(3) C 社製 }\end{array}$ & $\begin{array}{l}\text { (1) } 0.98 \\
\text { (2) } 1.23 \\
\text { (3) } 0.88\end{array}$ \\
\hline G) & $\begin{array}{l}\text { ノートパソコン(98 年製造、日本製)各部 } \\
\text { (1)ケーシング、(2)キーボード、(3)ディスプレイ }\end{array}$ & $\begin{array}{l}\text { (1) } 1.60 \\
\text { (2) } 1.30 \\
\text { (3) } 3.30\end{array}$ \\
\hline
\end{tabular}

[TIC Abundance]

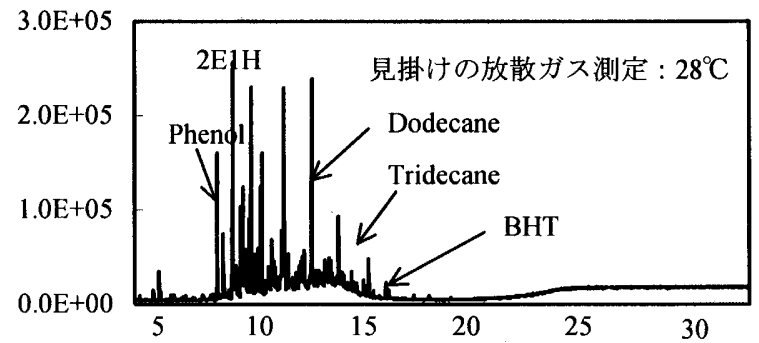

[TIC Abundance] R.T.[min]

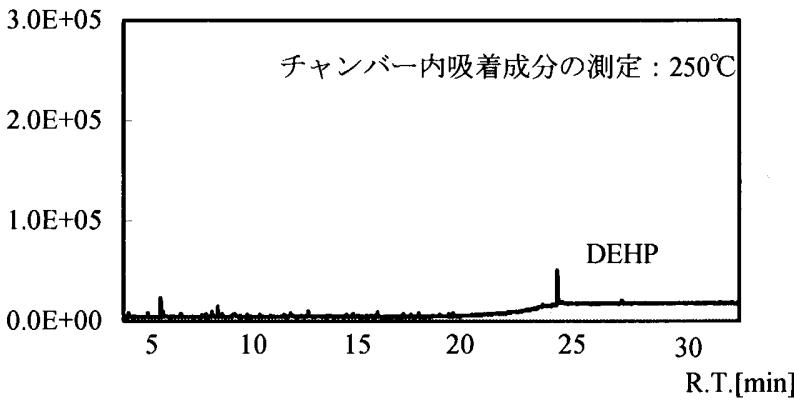

図 10 床材の TIC 応答

D) カーペット(表 $\left.4: 28^{\circ} \mathrm{C}, 40^{\circ} \mathrm{C}\right)$

SVOCs は、チャンバー内吸着成分の測定においても検出されなか った。VOCs としては、28 C Cでは、見掛けの放散ガスの測定で $2 \mathrm{E} 1 \mathrm{H}$

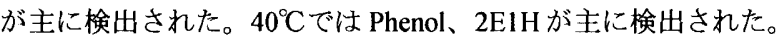

E) 防炎力ーテン (表 $\left.4: 28^{\circ} \mathrm{C}, 40^{\circ} \mathrm{C}\right)$

$28^{\circ} \mathrm{C}$ で最も多く放散したのは、チャンバー内吸着成分として検出

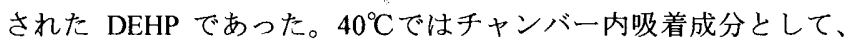
DBP、DEHP が検出され、放散速度は $28^{\circ} \mathrm{C}$ 条件下の約 10 倍であった。 F)ソファーのレザーカバー(表 $5: 28^{\circ} \mathrm{C}$ )

市販のフェイクレザー 3 種類を測定し、放散成分を比較した。

(1)A社製

チャンバー内吸着成分の測定では、DEHP が検出された。見措けの 放散ガスの測定では、VOCs として Toluene、p-Xylene、2E1H が主に 検出された。

(2) B社製

チャンバー内吸着成分の測定では、DBP、DEHP が検出された。見 掛けの放散ガスの測定では、VOCs として Toluene、p-Xylene、2E1H が主に検出された。 
表4 各種建材からの平均放散速度

\begin{tabular}{|c|c|c|c|c|c|c|c|}
\hline & \multirow[b]{2}{*}{$\begin{array}{c}\text { 検出された } \\
\text { 主な化学物質 } \\
\text { (検出順に記載) }\end{array}$} & \multicolumn{3}{|c|}{$28^{\circ} \mathrm{C}$ 測定 } & \multicolumn{3}{|c|}{$40^{\circ} \mathrm{C}$ 測定 } \\
\hline & & $\begin{array}{c}\text { 見掛け } \\
\text { の放散量 } \\
\times 10^{-3}[\mu \mathrm{g} / \mathrm{h}] \\
\end{array}$ & $\begin{array}{c}\text { チャンバー内 } \\
\text { 吸着量 } \\
\times 10^{-3}[\mu \mathrm{g} / \mathrm{h}] \\
\end{array}$ & $\begin{array}{c}\text { 放散速度 } \\
{\left[\mu \mathrm{g} /\left(\mathrm{m}^{2} \mathrm{~h}\right)\right]}\end{array}$ & $\begin{array}{c}\text { 見掛け } \\
\text { の放散量 } \\
\times 10^{-3}[\mu \mathrm{g} / \mathrm{h}] \\
\end{array}$ & $\begin{array}{c}\text { チャンバー内 } \\
\text { 吸着量 } \\
\times 10^{-3}[\mu \mathrm{g} / \mathrm{h}] \\
\end{array}$ & $\begin{array}{l}\text { 放散速度 } \\
{\left[\mu \mathrm{g} /\left(\mathrm{m}^{2} \mathrm{~h}\right)\right]}\end{array}$ \\
\hline $\begin{array}{l}\text { A) } \\
\text { 防ダ二 } \\
\text { 断熱材 }\end{array}$ & $\begin{array}{c}2 \mathrm{E} 1 \mathrm{H} \\
\text { Diphenyl Sulfone } \\
\text { DEHP } \\
\end{array}$ & $\begin{array}{l}396 \\
\text { N.D. } \\
\text { N.D. }\end{array}$ & $\begin{array}{c}7 \\
12 \\
16 \\
\end{array}$ & $\begin{array}{c}82 \\
2 \\
3 \\
\end{array}$ & $\begin{array}{c}416 \\
1 \\
\text { N.D. } \\
\end{array}$ & $\begin{array}{c}\text { N.D. } \\
12 \\
81 \\
\end{array}$ & $\begin{array}{c}85 \\
2 \\
16 \\
\end{array}$ \\
\hline $\begin{array}{l}\text { B) } \\
\text { 床材 }\end{array}$ & $\begin{array}{c}\text { Phenol } \\
2 \mathrm{E} 1 \mathrm{H} \\
\text { BHT } \\
\text { DEHP }\end{array}$ & $\begin{array}{c}446 \\
1020 \\
30 \\
\text { N.D. } \\
\end{array}$ & $\begin{array}{c}2 \\
16 \\
\text { N.D. } \\
129 \\
\end{array}$ & $\begin{array}{c}91 \\
211 \\
6 \\
26 \\
\end{array}$ & $\begin{array}{c}1634 \\
5320 \\
330 \\
\text { N.D. } \\
\end{array}$ & $\begin{array}{c}\text { N.D. } \\
31 \\
\text { N.D. } \\
360 \\
\end{array}$ & $\begin{array}{c}333 \\
1092 \\
67 \\
73 \\
\end{array}$ \\
\hline $\begin{array}{l}\text { C) } \\
\text { 壁紙 }\end{array}$ & $\begin{array}{l}\text { Phenol } \\
2 \mathrm{E} 1 \mathrm{H}\end{array}$ & $\begin{array}{c}32 \\
368 \\
\end{array}$ & $\begin{array}{l}\text { N.D. } \\
\text { N.D. }\end{array}$ & $\begin{array}{c}6.63 \\
75 \\
\end{array}$ & $\begin{array}{c}106 \\
1394 \\
\end{array}$ & $\begin{array}{l}\text { N.D. } \\
\text { N.D. }\end{array}$ & $\begin{array}{c}21 \\
284 \\
\end{array}$ \\
\hline $\begin{array}{l}\text { D) } \\
\text { カーペット }\end{array}$ & $\begin{array}{c}\text { Phenol } \\
2 \mathrm{E} 1 \mathrm{H}\end{array}$ & $\begin{array}{c}\text { N.D. } \\
161\end{array}$ & $\begin{array}{c}\text { N.D. } \\
17 \\
\end{array}$ & $\begin{array}{c}\text { N.D. } \\
36\end{array}$ & $\begin{array}{l}704 \\
546 \\
\end{array}$ & $\begin{array}{l}\text { N.D. } \\
16.4 \\
\end{array}$ & $\begin{array}{l}144 \\
115 \\
\end{array}$ \\
\hline $\begin{array}{l}\text { E) } \\
\text { 防炎カーテン }\end{array}$ & $\begin{array}{l}\text { DBP } \\
\text { DEHP }\end{array}$ & $\begin{array}{l}\text { N.D. } \\
\text { N.D. }\end{array}$ & $\begin{array}{c}\text { N.D. } \\
20\end{array}$ & $\begin{array}{c}\text { N.D. } \\
4\end{array}$ & $\begin{array}{l}\text { N.D. } \\
\text { N.D. }\end{array}$ & $\begin{array}{l}19.2 \\
210\end{array}$ & $\begin{array}{c}3 \\
43\end{array}$ \\
\hline
\end{tabular}

※Diphenyl Sulfone, Phenol : Toluene 換算

\section{(3) C 社製}

チャンバー内吸着成分の測定では、DEHP が検出された。見掛けの 放散ガスの測定では、VOCs として Toluene、p-Xylene、2E1H が主に 検出された。2E1H の放散速度が $75 \mu \mathrm{g} /\left(\mathrm{m}^{2} \mathrm{~h}\right) 、 \mathrm{DEHP}$ の放散速度が $42 \mu \mathrm{g} /\left(\mathrm{m}^{2} \mathrm{~h}\right)$ と多量に放散され、今回測定した試験片の中で、 $28^{\circ} \mathrm{C}$ 条 件下で最も多量に DEHPが放散されている。

G) ノートパソコン各部(表 $6: 40^{\circ} \mathrm{C}$ )

(1) ケーシング

ABS 樹脂と表示されている。SVOCs として、見掛けの放散ガスの 測定では、DEP(Diethyl phthalate) 、DBPが検出され、チャンバー内吸 着成分の測定では、DBP、DEHP 等のフタル酸エステル類が検出され た。

(2)キーボード

チャンバー内吸着成分の測定では、DEHP等のフタル酸エステル類 が検出された。見掛けの放散ガスの測定では、VOCs として Styrene が検出された。

(3)ディスプレイ

SVOCs として、見掛けの放散ガスの測定では BHT が検出されたが、 チャンバー内吸着成分の測定では、フタル酸エステル類はほとんど 検出されなかった。VOCs として、チャンバー内吸着成分の測定では、 Toluene が放散速度 $2121 \mu \mathrm{g} /\left(\mathrm{m}^{2} \mathrm{~h}\right)$ で多量に放散されている。

\section{4 材料からの放散速度に関する考察}

6.3に記したように、多くの材料から $28^{\circ} \mathrm{C}$ 条件下で DEHP が検出さ れた。最も放散速度の大きい材料はソファーのレザーカバー( $\mathrm{C}$ 社製) で、 $42 \mu \mathrm{g} /\left(\mathrm{m}^{2} \mathrm{~h}\right)$ であった。一方、同製品から検出されたトルエンも $30 \mu \mathrm{g} /\left(\mathrm{m}^{2} \mathrm{~h}\right)$ と同程度放散されており、この点から両物質の物性值を 比較し、結果の妥当性について検討する。

材料からの化学物質の放散速度を決定する物性值の1つに蒸気圧が ある。DEHPは、常温 $\left(20 ~ 28^{\circ} \mathrm{C}\right.$ 程度)での蒸気圧を測定する事が難し く、様々な值が報告されているが、一例として $3.04 \times 10^{-5} \mathrm{~Pa}\left(20^{\circ} \mathrm{C}\right)$ 文 ${ }^{19)}$ 程度といわれている。一方、揮発性の高いホルムアルデヒドやト
表5 F)ソファーのレザーカバーからの平均放散速度( $28^{\circ}$ C 測定)

\begin{tabular}{|c|c|c|c|c|}
\hline & $\begin{array}{c}\text { 検出された } \\
\text { 主な化学物質 }\end{array}$ & \begin{tabular}{|c|} 
見掛けの \\
放散量 \\
$\times 10^{-3}[\mu \mathrm{gh}]$ \\
\end{tabular} & \begin{tabular}{|c|} 
チャンバー内 \\
吸着量 \\
$\times 10^{-3}[\mu \mathrm{g} / \mathrm{h}]$ \\
\end{tabular} & $\begin{array}{l}\text { 放散速度 } \\
{\left[\mu \mathrm{g} /\left(\mathrm{m}^{2} \mathrm{~h}\right)\right]}\end{array}$ \\
\hline \multirow{4}{*}{$\begin{array}{l}\text { (1) } \\
\mathrm{A} \text { 社製 }\end{array}$} & Toluene & 126 & N.D. & 25 \\
\hline & p-Xylene & 13 & N.D. & 2 \\
\hline & $2 \mathrm{E} 1 \mathrm{H}$ & 181 & N.D. & 36 \\
\hline & DEHP & N.D. & 48 & 9 \\
\hline \multirow{5}{*}{$\begin{array}{l}\text { (2) } \\
\text { B社製 }\end{array}$} & Toluene & 170 & N.D. & 34 \\
\hline & p-Xylene & 25 & N.D. & 5 \\
\hline & $2 \mathrm{E} 1 \mathrm{H}$ & 203 & N.D. & 41 \\
\hline & DBP & N.D. & 64 & 13 \\
\hline & DEHP & N.D. & 26 & 5 \\
\hline \multirow{4}{*}{$\begin{array}{l}\text { (3) } \\
C \text { 社製 }\end{array}$} & Toluene & 148 & N.D. & 30 \\
\hline & p-Xylene & 7 & N.D. & 1 \\
\hline & $2 \mathrm{E} 1 \mathrm{H}$ & 372 & N.D. & 75 \\
\hline & DEHP & N.D. & 206 & 42 \\
\hline
\end{tabular}

表6 G)ノートパソコンからの平均放散速度 $\left(40^{\circ} \mathrm{C}\right.$ 測定 $)$

\begin{tabular}{|l|c|c|c|c|}
\hline & $\begin{array}{c}\text { 検出された } \\
\text { 主化学物質 }\end{array}$ & $\begin{array}{c}\text { 見掛けの } \\
\text { 放散量 } \\
\times 10^{-3}[\mu \mathrm{g} / \mathrm{h}]\end{array}$ & $\begin{array}{c}\text { チャンバー内 } \\
\text { 吸着量 } \\
\times 10^{-3}[\mu \mathrm{g} / \mathrm{h}]\end{array}$ & $\begin{array}{c}\text { 放散速度 } \\
{\left[\mu \mathrm{g} /\left(\mathrm{m}^{2} \mathrm{~h}\right)\right]}\end{array}$ \\
\hline \hline (1) & $2 \mathrm{E} 1 \mathrm{H}$ & 274 & N.D. & 55 \\
& $\mathrm{DEP}$ & 960 & 15 & 191 \\
& $\mathrm{DBP}$ & 75 & 20 & 19 \\
& DEHP & N.D. & 162 & 33 \\
\hline \hline キージード & Styrene & 70 & 18 & 18 \\
\hline \hline (3) & DEHP & N.D. & 202 & 41 \\
ディスプレイ & Toluene & 10338 & 52 & 2121 \\
\hline
\end{tabular}


ルエンの蒸気圧は、それぞれ $517 \mathrm{kPa}\left(25^{\circ} \mathrm{C}\right)^{\text {文20) }}$ 、 $2.9 \mathrm{kPa}\left(25^{\circ} \mathrm{C}\right)^{\text {文21) }}$ で あり、これらと比較すると DEHPの蒸気圧は極めて低い。一般的に 蒸気圧が高い物質は、材料からの放散速度が大きい傾向があるが、 今回の測定では、DEHPのように蒸気圧が低い物質の放散速度も大き な值となった。

この原因として、材料に含まれる他の物質の影響を受けている可 能性が考えられる。DEHP 等の可塑剤の揮発性は、単独では物質固有 の沸点や蒸気圧に左右されるが、添加剤として用いられる場合には、 物質単独の性質とは異なり、材料に含まれる他の物質に左右される 可能性がある。特に相溶性の高い物質では、この傾向が見られる文22。

\section{7. 結論}

チャンバー内吸着 - 加熱脱着法による測定の精度検証として、 SVOCs 標準物質による回収率測定及び、塩化ビニル製の床材を用い た検証を行った。又、床材からの SVOCs 放散の特徴を調查した。さ らに上述の結果を踏まえ、各種建材 - 家具・家電製品の SVOCs 放散 量測定を行った。

1) チャンバーの回収率は 59〜98\%であった。

2) 床材を同一条件下において、5 回連続で測定した時、DEHP 放散 速度の変動係数は $22 \%$ であった。床材からの DEHP の平均放散 速度は $22 \mu \mathrm{g} /\left(\mathrm{m}^{2} \mathrm{~h}\right)$ であった。

3) 床材から放散される各物質の養生日数と放散量の関係を調査し た結果、DEHP は測定期間 6 日間では減衰傾向が見られず、平 均放散速度 $22 \mu \mathrm{g} /\left(\mathrm{m}^{2} \mathrm{~h}\right)$ であった。

4) 試験片の切り出し位置の違いによる放散速度のばらつきを調查 した。DEHPは、変動係数 $21 \%$ で、検出された主な化学物質の うち最も小さい值となった。

5) 床材・壁紙・カーペット等から、DEHP の分解物質である $2 \mathrm{E} 1 \mathrm{H}$ が顕著に検出された。防ダ二加工した断熱材、床材、防炎カー テンからは、チャンバー内吸着成分から DEHP 等のフタル酸エ ステル類が検出された。

6) 雰囲気温度 $40^{\circ} \mathrm{C}$ では、放散速度が $28^{\circ} \mathrm{C}$ 条件下の 2 5 倍となる 物質があった。

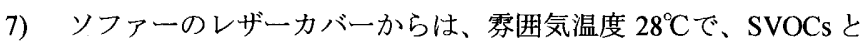
してDBP、DEHP等のフタル酸エステル類が多く検出された。

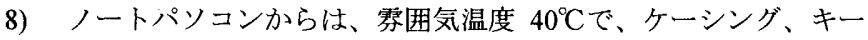
ボードから DEP、DBP、DEHP 等のフタル酸エステル類が検出 された。ディスプレイからは、SVOCs として BHT が検出され、 他にVOCsとして Tolueneが多量に検出された。

9）今後は、本測定法による測定を重祆、データベースを作成して いく予定である。

注粎

[1]無極性カラムでの分離条件で n-テトラデカン〜n-へキサコサンの間で溶出す る有機物と定義する文23)。

[2]ここで表記する線り返し再現性とは、同一試験片を同一の測定者が数回測定 しだときのばらつきを意味する。

[3]見掛けの放散ガスの測定により検出される化学物質は、大半が VOCsであり、 SVOCsはほとんど捕集されない。

[4]GC/MS 分析条件

\begin{tabular}{|c|c|}
\hline $\mathrm{GC}$ & $\mathrm{HP} 6890$ \\
\hline $\begin{array}{c}\text { コールドトラップ } \\
\text { 温度 }\end{array}$ & $-130^{\circ} \mathrm{C}(1.5 \mathrm{~min}) \rightarrow 50^{\circ} \mathrm{C} / \mathrm{sec} \rightarrow 250^{\circ} \mathrm{C}(4 \mathrm{~min})$ \\
\hline カラム & $\mathrm{TC}-5(30 \mathrm{~m} \times 0.25 \mathrm{~mm} \times 0.25 \mu \mathrm{m})$ \\
\hline オーブン温度 & $40^{\circ} \mathrm{C}(5 \mathrm{~min}) \rightarrow 10^{\circ} \mathrm{C} / \mathrm{min} \rightarrow 270^{\circ} \mathrm{C}(21 \mathrm{~min})$ \\
\hline 検出器 $(\mathrm{MS})$ & $\mathrm{HP} 5973 \mathrm{MSD}$ \\
\hline
\end{tabular}

[5]ここで換気回数 $\mathrm{n}=9.5$ 回 $/ \mathrm{h}$ 、試料負荷率 $\mathrm{L}=12.6 \mathrm{~m}^{2} / \mathrm{m}^{3}$ より $\mathrm{L} / \mathrm{n}=1.3$ 。チャンバ 一試験では、L/nが 0.5 10 の時、室内環境を再現出来ていると考える。又、L/n が小さいほど、放散速度は大きくなり安全側で評価していると考えられる文 24) [6]回収率は、Tenax-TA 管に一定量の SVOCs 標準物質を直接添加して定量分析 した結果を $100 \%$ とする。

[7]チャンバー底面に約 $1 \mathrm{~mm}$ の突起があり、ガラス台の設置により給気ロ 2 を
塞ぐことはない。

[8]デシケータに供給される空気の温湿度は、給気口の直前で測定しており、温 度はほぼ $23 \pm 11^{\circ} \mathrm{C}$ 、相対湿度約 $60 \pm 5 \%$ 程度である。(1)シリカゲルで除湿し、(2) 活性炭を用いて VOCs を除去し、この空気の一部を(3)水でバブリング(Wet Air) させ乾燥空気(Dry Air)と混合させ、湿度調節を行っている。

[9]見掛けの放散ガスの測定後、チャンバーから取り出した試験片は、吸着成分 の加熱脱着中、デシケータ内に戻す。

\section{觓辞}

研究の遂行にあたり、朱清宇氏(当時 : 東京大学生産技術研究所)、 徐長厚氏(東京大学生産技術研究所)、横田知博氏(当時 : 慶應義塾大 学大学院)に多大なご協力をいただいた。ここに記して深甚の謝意を 表する。本研究の一部は、建築学会特別調查委員会・シックハウス問 題の解明とへルシーな居住環境の開発特別研究委員会(委員長:村上周 三 慶應義塾大学理工学部 教授)の活動の一環として実施したものであ る。本研究の一部は国土交通省の建設技術開発費補助金の助成を得て 実施している事を付記する。

\section{参考文献}

[1]JIS A 1901 : 建築材料の揮発性有機化合物(VOC)、ホルムアルデヒド及び他 のカルボニル化合物放散測定方法一小型チャンバー法, 2003.1

[2]可塑㓮工業会：生産出荷統計データ, http://www.kasozai.gr.jp/

[3]Carl-Gustaf Bornehag, Charles J. Weschler : The Association between Asthma and Allergic Symptoms in Children and Phthalates in House Dust: A Nested Case-Control Study, Environmental Health Perspectives, Vol. 112, Num14, pp1393 -1397, 2004.10 [4] 野中辰夫,竹田菊男,大橋一俊,藤井博史,村上高行,藤本武利：住宅建材の放散 ガス評価における実用的な加速試験法, 2001年度室内環境会 ,pp208-211, 2001.12 [5]JACA No.34-1999：クリーンルーム構成材料から発生する分子状污染物質の 測定方法指針, 日本空気清浄協会, 1999

[6]藤本武利,竹田菊男,野中辰夫,飯田裕幸,中原武利：クリーンルーム構成材料 および樹脂材料の発生ガス試験,エアロゾル研究14(4)pp348-356 1999

[7]E.Uhde, M.Bednarek, F. Fuhrmann, T.Salthammer : Phthalic Esters in the Indoor Environment-Test chamber Studies on PVC-Coated Wall - coverings , Indoor Air , pp150-155 2001.11

[8]本橋健司,今井誠弘, : ポリ塩化ビニル樹脂系建築材料から放散するフタル酸 エステル類の定量分析, 日本建築学会構造系論文集, 第 573 号, pp15-20, 2003.11 [9]星野邦広，今中努志，加藤信介，朱清宇，安宅勇二安福勝：実温度条件下にお ける材料から放散される半揮発性有機化合物 (SVOC) 測定に関する研究(その 1) : チャンバー内吸着一加熱脱着法の開発, 日本建築学会大会学術講演梗概集, D-2, pp857-858, 2002.8

[10]朱清宇,星野邦広, 加藤信介,安宅勇二, 安福勝: 実温度条件下における材料か ら放散される半捙発性有機化合物（SVOC）測定に関寸る研究(その 2) : 建材、 家電製品からのS SVOC 放散量の測定，日本建築学会大会学術講演梗概集，D-2, pp859-860, 2002.8

[11] 星野邦広, 今中努志, 加藤信介, 朱清宇, 安宅勇二, 安福勝 : 実温度条件下にお ける材料から放散される半揮発性有機化合物 (SVOC) 測定に関寸る研究(その 3) : チャンバー内吸着加熱脱着法の測定条件の検討と家電製品からの SVOC 放 散量の測定, 日本空気調和·衛生工学 学術講演梗概集, pp637-640, 2002.9

[12]K Hoshino, T Imanaka, T Iwasaki, S Kato : Study on measurement of semi volatile organic compounds (SVOCs) emitted from indoor materials and products using glass test chamber, Indoor Air $20029^{\text {th }}$ International Conference on Indoor Air Quality and Climate, Vol.2, pp950-954, 2002.6

[13]朱清宇, 星野邦広,加藤信介,安宅勇二：実温度条件下における材料から放散 される準揮発性有機化合物(Semi-Volatile Organic Compounds：SVOCs)測定法の 開発，日本建築学会環境系論文集,第 574 号,pp35-41,2003.12

[14]星野邦広,今中努志,加藤信介,朱清宇,安宅勇二：実温度条件下に打ける材料 から放散される半揮発性有機化合物(SVOC)測定に関する研究(その 4) : チャン バー一内吸着-加熱脱着法によるノ‥トパソンンから放散される SVOC の測定，日 本建筑学会大会学術講演梗概集,D-2, pp959-960,2003.8

[15]勝又寛子, 村上周三,加藤信介,朱清字, 星野邦広, 安宅勇二, 横田知博 : 実温度条 件下における材料から放散される半揮発性有機化合物（SVOC）測定に関する 研究(その 6): 建材·家電製品からの放散量測定, 日本建築学会大会学術講演梗 概集,D-2, pp949-950, 2004.8

[16]勝又寛子,横田知博,村上周三, 加藤信介,朱清宇,星野邦広,安宅勇二 : 実温度 条件下における材料から放散される半揮発性有機化合物（SVOC）測定に関す る研究(その 7) : 2つのマイクロチャンバー-流れ場の数值解析

日本空気調和·衛生工学 学術講演梗概集, pp1415-1418, 2004.9

[17]安藤正典 : 室内空気污染と化学物質,化学工業日報社,2002.10

[18]14102の化学商品,化学工業日報社,2002 .1

[19] 有害性評価書 CAS 登録番号 117-81-7,化学物質評価研究機構,2004.9

[20] 有害性評価書 CAS 登録番号 50-00-0,化学物質評価研究機構,2005.2

[21] シック八ウスを防ぐ最新知識-健康な住まいづくりのために-,日本建築学 会, 2005.3

[22]中條澄 : エンジニアのためのプラスチック教本,工業調査会,1997.12

[23]中小企業基淮認証研究開発事業(建材からの VOC 等放散量の評価方法に関 する標準化)成果報告畫,建材試験センター,2005.3

[24]建材とホルムアルデヒド・VOC 小型チャンバー法による測定法 JIS(案)講演 会梗概集,建材試験センター-,2002.6 